Iranian Quarterly Journal of Breast Disease 2018; 11(4):28.

\title{
Effects of a Rational Emotive Behavior Therapy-Based Education Program on Marital Stress in Couples Coping with Breast Cancer
}

Pirmardvand Chegini B: Department of Counseling, Faculty of Psychology and Educational Sciences, Kharazmi University, Tehran, Iran

Zahrakar K: Department of Counseling, Faculty of Psychology and Educational Sciences, Kharazmi University, Tehran, Iran

Sanai Zaker B: Department of Counseling, Faculty of Psychology and Educational Sciences, Kharazmi University, Tehran, Iran

Corresponding Author: Bahman Pirmardvand Chegini, Bahmanchegini8@gmail.com

\begin{abstract}
Introduction: Being diagnosed with breast cancer is usually associated with stress, and the overflow of this stress in the form of marital stress affects the marital relationship of couples. The purpose of this study was to determine the effect of an education program based on rational emotive behavior therapy (REBT) on marital stress of couples coping with breast cancer in Qazvin.
\end{abstract}

Methods: The method of this study was semi-experimental and its design was pretest and posttest with a control group. The population of the present study included all the couples with breast cancer who visited Velayat hospital in Qazvin province in October 2018. Sixty women were selected via available sampling and tested. Of them, 18 women, along with their husbands (18 couples), who had a score above average on the marital stress scale were selected and randomly assigned to two groups. The experimental group received 82 -hour sessions of education based on REBT. The research instrument was the Stockholm-Tehran Marital Stress Scale (STMSS). Data were analyzed using covariance analysis.

Results: The experimental group had significantly lower marital stress compared with the control group $(\mathrm{p}<0.001)$.

Conclusion: Based on the findings of this research, it can be concluded that education based on REBT reduces marital stress of couples who are coping with breast cancer.

Keywords: Rational Emotive Behavior Therapy, Marital Stress, Breast Cancer 


\title{
اثربخشى آموزش مبتنى بر درمان عقلانى- هيجانى- رفتارى بر استرس زناشويى زوجين مبتلا به سرطان بـتان
}

\author{
بهمن بِيرمردوند حَّينى": كروه مشاوره، دانشكده روانشناسى و علوم تربيتى، دانشكاه خوارزمى، تهر ان، ايران

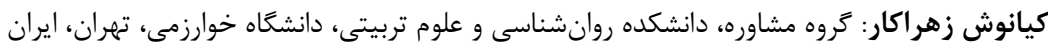

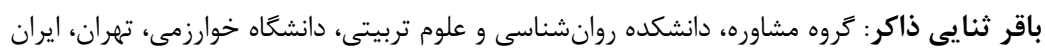

\section{جكيده}

مقدمه: سرطان يستان بيمارى است كه تشخيص آن به خودى خود استرسزاست و سرريز اين استرس به شكل استرس زناشويى بر رابطه زوجين تاثير مى كذارد. هدف اين يزوهش تعيين اثربخشى آموزش مبتنى بر درمان عقلانى- هيجانى-رفتارى بر استرس زناشويى زوجين مبتلا به سرطان يستان شهر قزوين بودئ

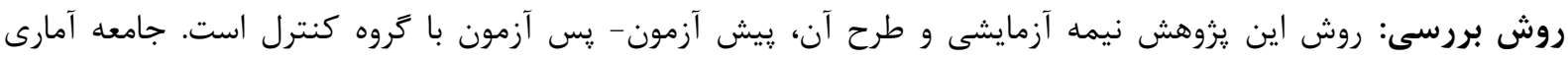

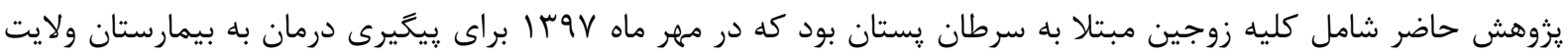

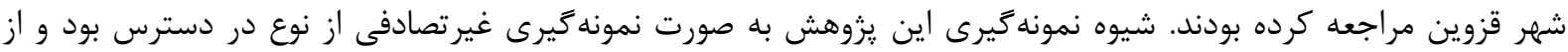

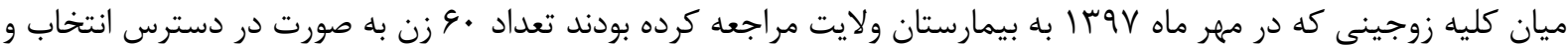

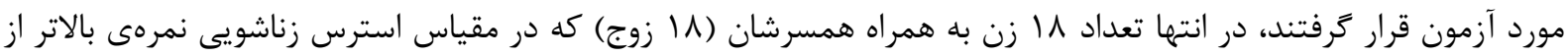

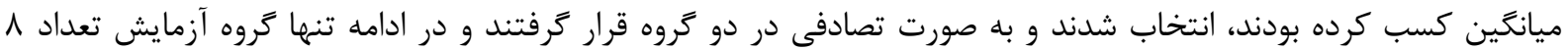

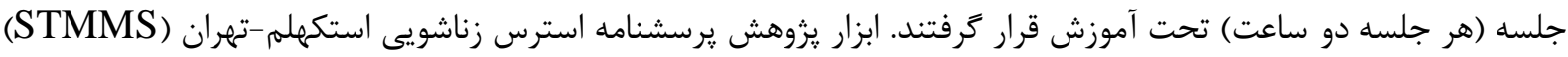
بود. و دادها با استفاده از روش تجزيه و تحليل كوواريانس تحليل شدند.

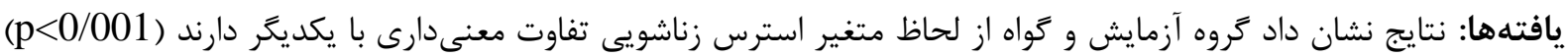

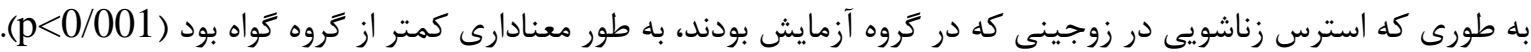
نتيجهَيرى: براساس يافتههاى اين يزوهش مى توان نتيجه كرفت كه آموزش درمان عقلانى - هيجانى - رفتارى موجب كاهش

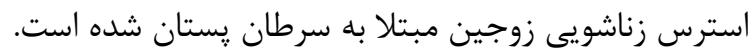

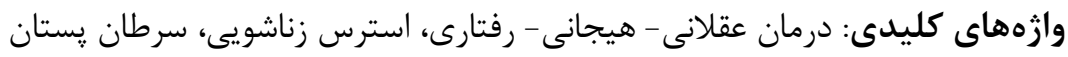


شود، مىتواند در كمك به آنها براى فعاليت بهتر،

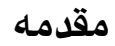

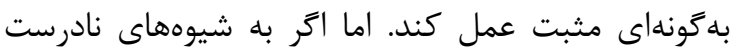

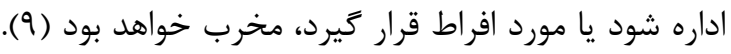

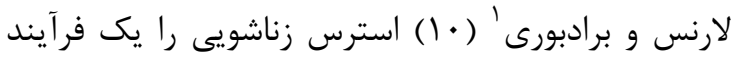

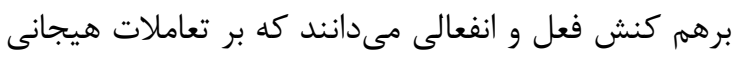
و رفتارى زوجين با يكديگر تاثير مى گذارد. رِوِنسون، كايزر

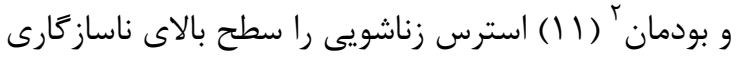
عاطفى مىدانند كه بر عواطف و رفتار هريك از زوجئ رونين، تعاملات زن- شوهر و ادراكات هريك از زوجين از رفتار ديكرى تاثير كذاشته و بر تعارضات زناشويى و مشكلات

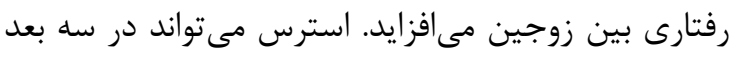

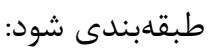
1- راهى كه هر دو شريك از واقعه استرسزا تاثير مى يذيرند (مستقيم يا غيرمستقيم)

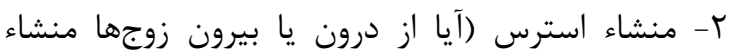

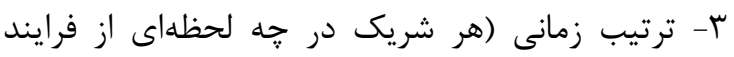
مقابله دركير مىشود) (T) (I ). با توجه به اين كه استرس زناشويى بخشى از استرس

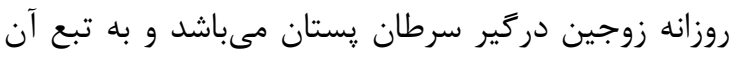

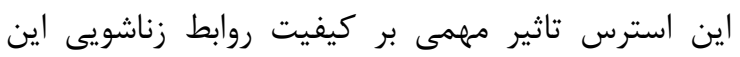

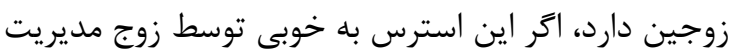
نكردد، آثار مخربى به صورت مستقيم و غيرمستقيم بر

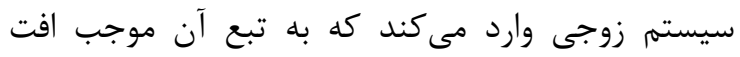
كيفيت روابط زناشويى مىشود. زوجينى كه دركير سر سرطان يستان هستند، بالطبع استرس زناشويى زيادى را در رابطه

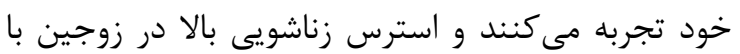

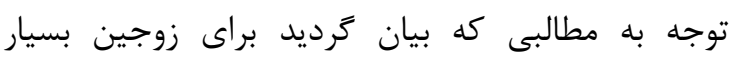

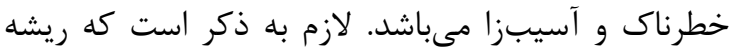

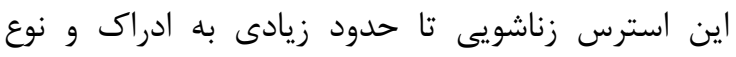

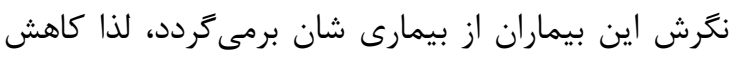

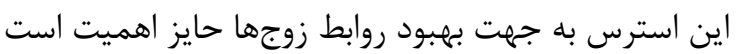

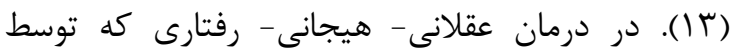

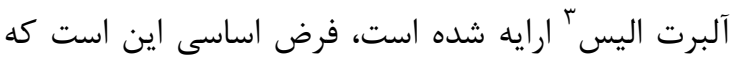

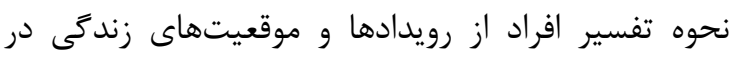

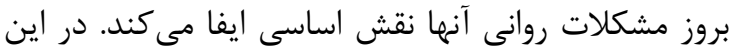

\footnotetext{
${ }^{1}$ Lorens \& Bradbouri

${ }^{2}$ Revenson, Kayser \& Bodenmann

${ }^{3}$ Albert Ellis
}

سرطان يستان شايعترين نوع سرطان در زنان مىباشد كه خه

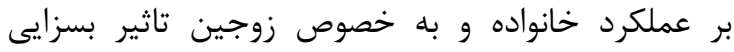

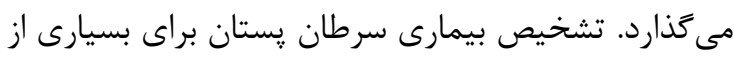

زنان واقعهاى مصيبت بار و ترسناك تلقى مىشود (1). در واقع سرطان يستان بيمارى است كه بيشتر از آنكه

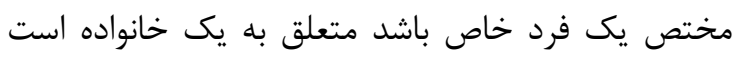

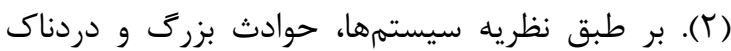

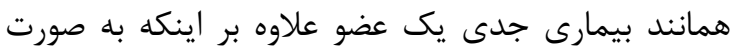
مستقيم بر خود فرد اثر مى كذارد به صورت غيرمستقيم بر بر بران

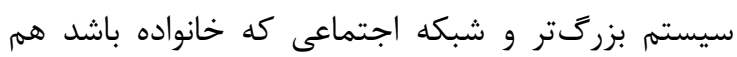
تاثير مى گذارد (ए). بلهطورى كه حتى همسران بيماران

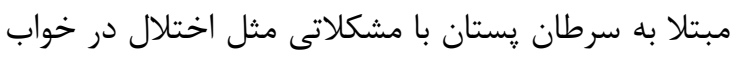

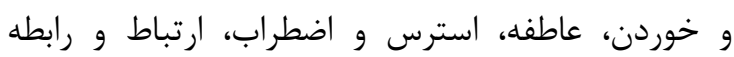
جنسى و كار و حتى كيفيت يايين روابط زناشويى مواجه مىشوند (Y). نتايج مطالعات نشان دادهاند كه همسران

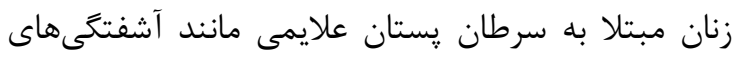
روانى - جنسى و استرس (ه) و افت كيفيت روابط زناشويى ندان

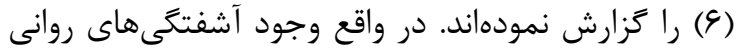
(مثل استرس، اضطراب، خلق افسرده و نشانههاى جسمانى

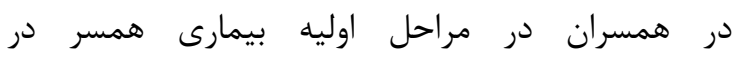
يزوهشهايى كه از ابزارهاى استاندارد همانند مصاحبههاى كيفى استفاده مىكنند به وضوح اثبات شده است و

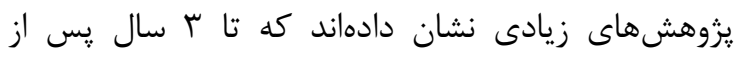

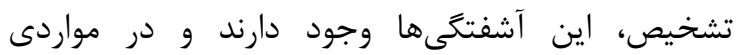
مطالعات نشان داده است كه آشفتگى هاى همسر و مراقبان

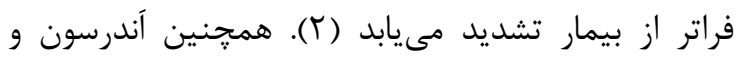

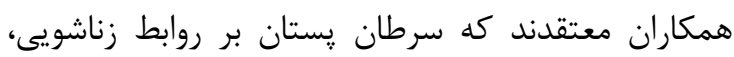
تمايلات جنسى، تصوير بدن و روابط صميمانه زوجين ردارن

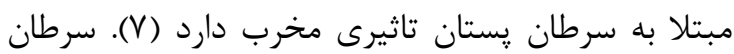

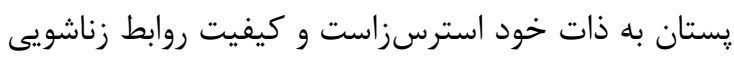
زوجين را تا حدود زيادى تحت شعاع قرار مىدهد (^). استرس زناشويى در واقع به عنوان نوعى استرس روانى - زئس

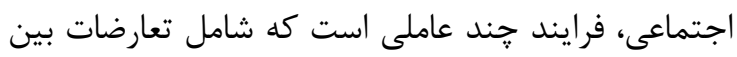

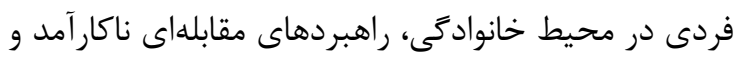
همراه با مجموعهاى از ياسخهاى عصبى - غددى، عملكرد

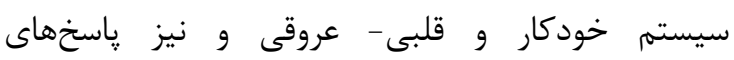
فيزيولوزيك به تنشهاى روانى و اجتماعى است (9). استرس زناشويى جنانجه توسط زوجين به خوبى زئى اداره 
رفتارى بر استرس زناشويى زوجين مبتلا به سرطان يستان

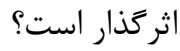

\section{مواد و روشها}

در اين يزوهش، جامعه آمارى، عبارت است از كليه

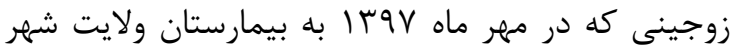
قزوين مراجعه كرده بودند و حداقل يكى از مران مراحل

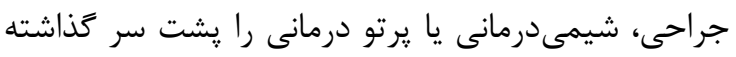

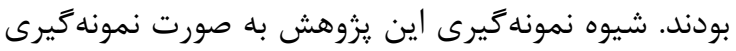
غيرتصادفى و از نوع در دسترس بود و از ميان كليه

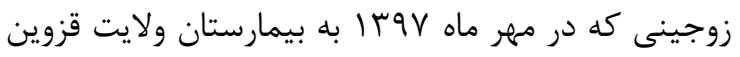

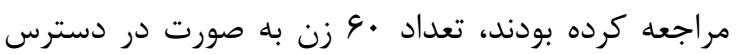
انتخاب شدند و يرسشنامه استرس زناشويى به آنها داده

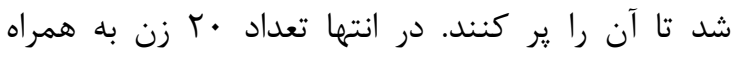

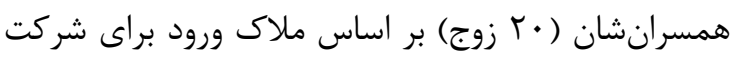
در يزوهش (1- يشت سر كذاشتن يكى از مراحل درمان

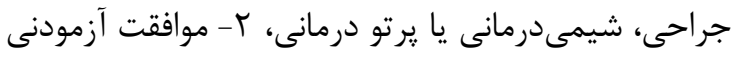

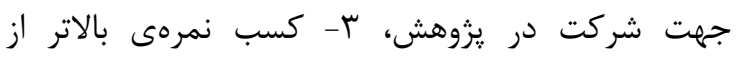
ميانگين در آزمون استرس زناشويى و ع آ- آزمودنىها در 4

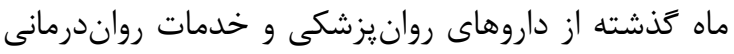

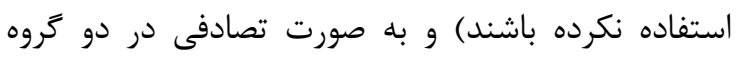

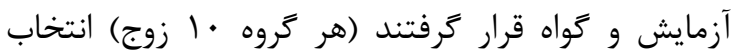
شدند. در ادامه فقط گروه آزمايش به مدت هشت خرك جلسه

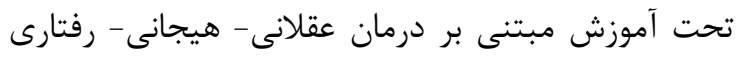
آلبرت اليس قرار كرفتند. محتواى آموزش تحت نقان نظارت اساتيد همكار در يزوهش و با نظارت آنها توسط نويسنده مسئول به مدت ^ جلسه (هر جلسه دو ساعت) به زوجين

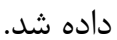
لازم به ذكر است كه از ميان •r زوج (•l زن و مرد) كه

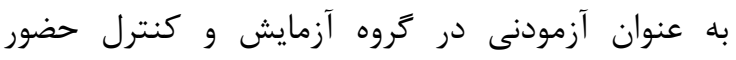

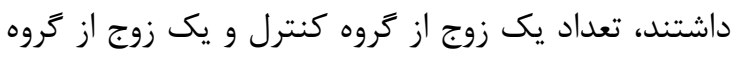

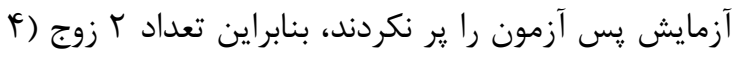

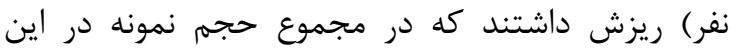

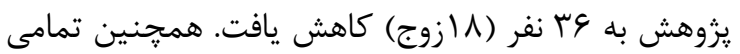

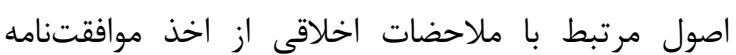
كتبى، رضايت آكاهانه براى شركت در جلسات احتات درمان، آنان حفظ رازدارى و محرمانه ماندن اطلاعات زوجين، رعايت حقوق شركت كنندگان، اختيارى بودن مشاركت و همكارى زوجين با روند يزوهش و حتى اختيارى بودن ترى جلسه
رويكرد اعتقاد بر اين است كه شناخت، هيجان و رفتار به شكل معنادارى با هم در تعامل هستند و بر يكديكر تاثير

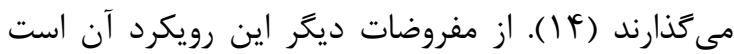

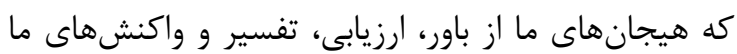
به موقعيتهاى زندگى ناشى مىشوند. ازطريق فرايند

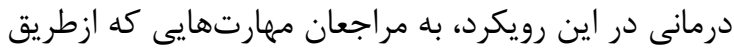
آنها باورهاى غيرعقلانى شناسايى و وبا آنها مقابله كرددد،

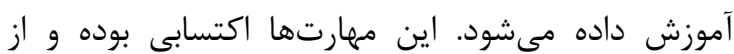
طريق خودتلقينى تداوم مىيابند. مراجعان مى آموزند كه

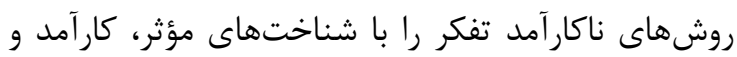

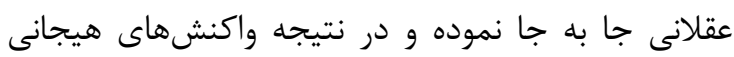
خود را به موقعيتها تغيير دهند (ها (1). در اين رويكرد درمانى اعتقاد بر اين است كه انسانها به دهان الهان

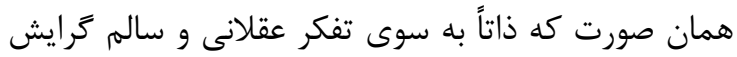
دارند، به سمت تفكرهاى نادرست و غيرعقلانى نيز متمايل بوده و اين تفكرها ريشه آشفتگىهاى هيجانى مى باشندا.

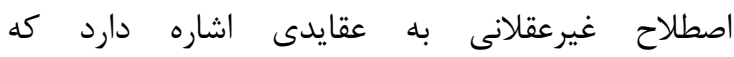
انعطافنايذير، مغاير با واقعيت و غيرمنطقى باشد و باعث كاهش سطح سلامت روانى فرد و مانع دستيابى او به به به باني اهداف مى كردد (ع). افكار غيرعقلانى بسيار يرهزينه و زيانبار بوده و باعث افزايش بروز استرس و و مشكلات إنات

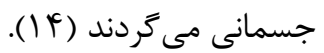

از طريق الكوى ABC مى توان ارتباط بين عقايد، رفتار و

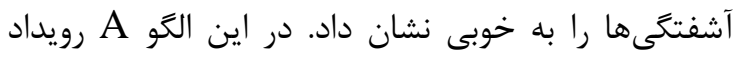

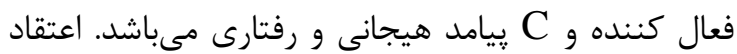
بر اين است كه A موجب C نمى كردد، بلكه B يا عقايد

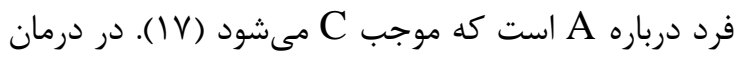

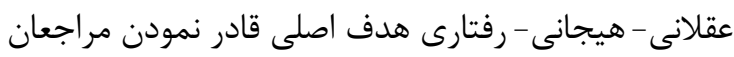
از طريق كسب فلسفه واقع بينانهتر درباره زندكى، مبارزه با هانيا

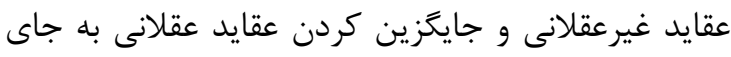

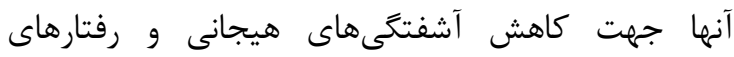

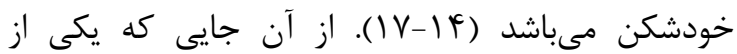
ريشههاى اصلى استرسهاى زوجين مبتلا به سرطان

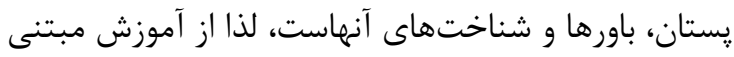

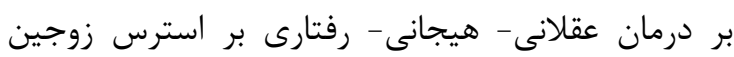

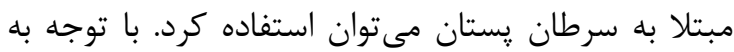

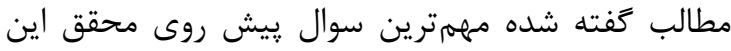

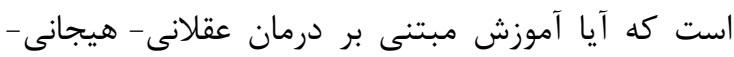


شامل برابرى واريانسها، همخنى شيب ركرسيون و نرمال

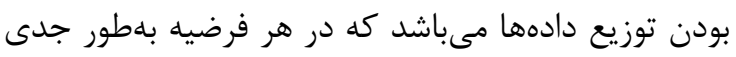

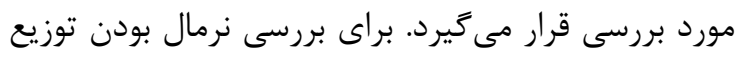

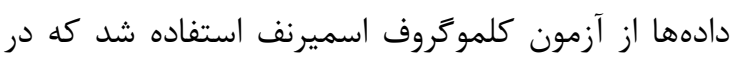

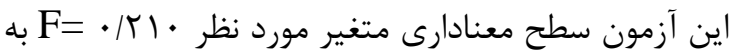

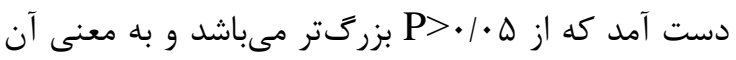

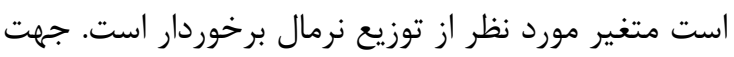

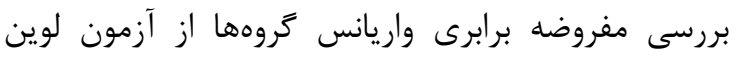

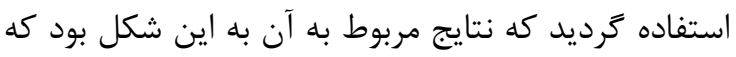

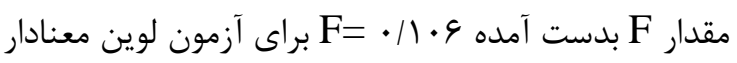

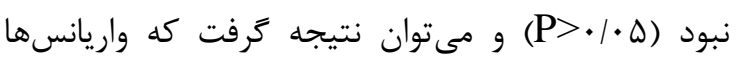
همخون بوده و آزمون تحليل كوواريانس مقدور است. نتان

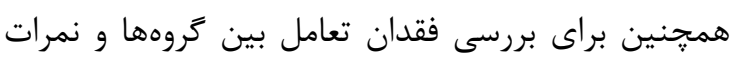

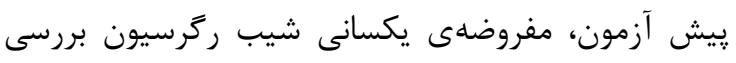

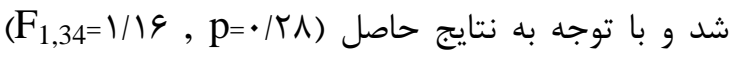

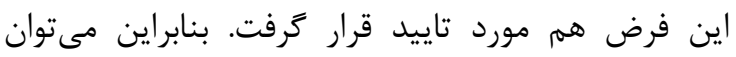

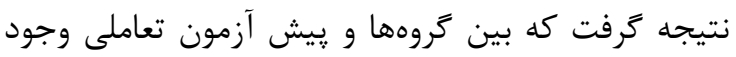

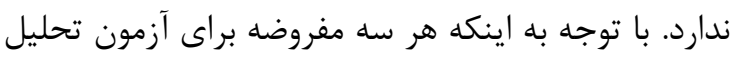

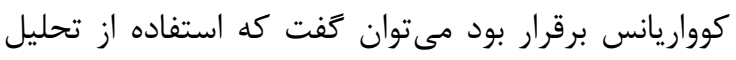

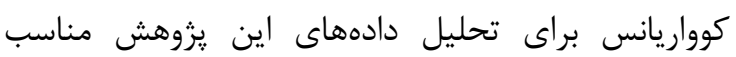

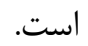

محتواى جلسات آموزش: محتواى جلسات آموزش دئ

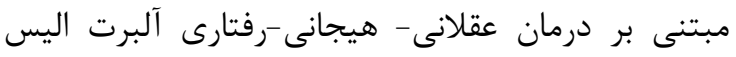

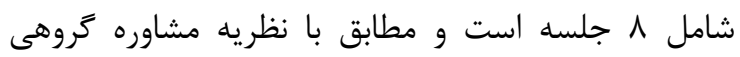

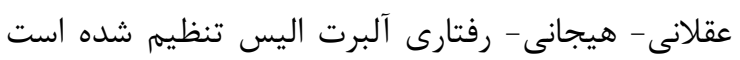

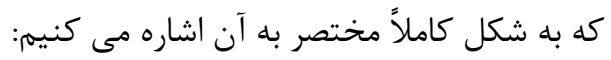
جلسه اول: معارفه اعضاى گروه به يكديخر، توضيح درباره

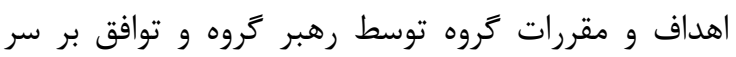

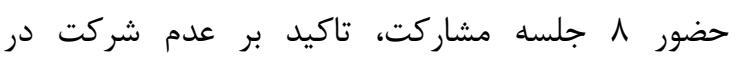

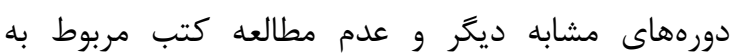

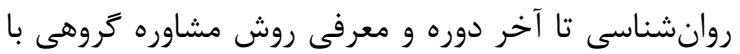
رويكرد عقلانى - هيجانى - رفتارى. جلسه دوم: بررسى و بيان مشكلات اعضا و ايجاد انكيزه

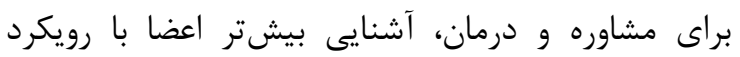

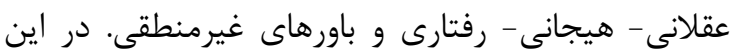

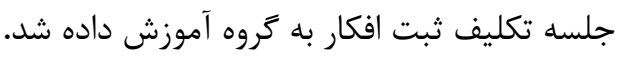

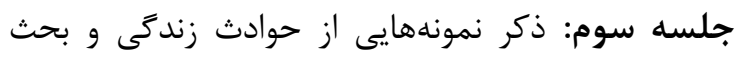

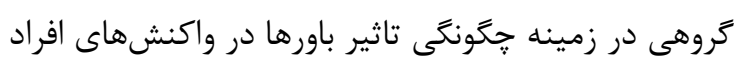

درمان با هماهنكى و صدور كد اخلاق با شناسه

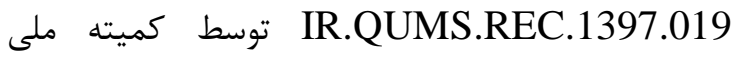
اخلاق در يزوهشهاى زيست يزشكى دانشكاه علوم يزشكى استان قزوين رعايت شده است.

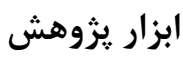

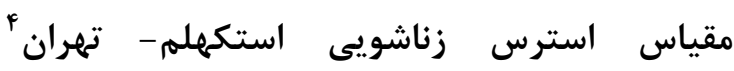

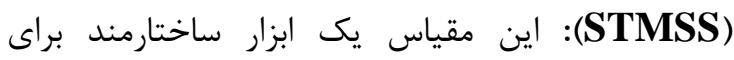

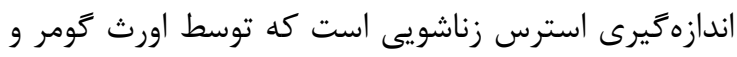

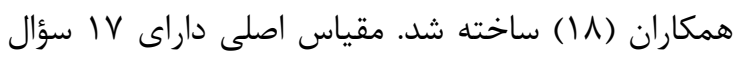

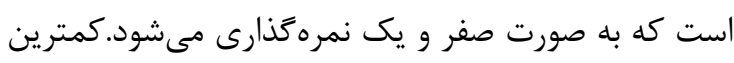

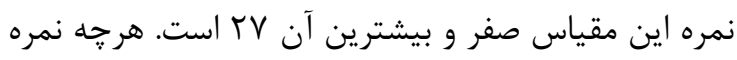
فرد در اين مقياس بالاتر باشد، استرس موجود در در روابط او

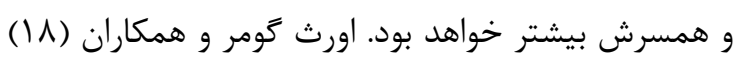

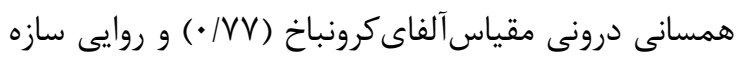
آن را با استفاده از مقياسئهاى مرتبط، رضايتبخش

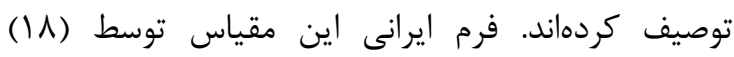

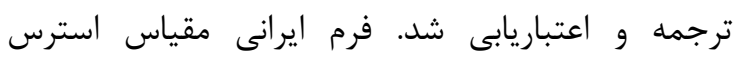

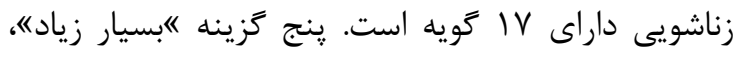

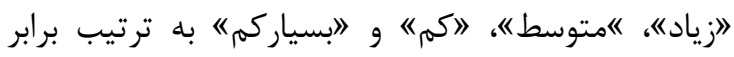

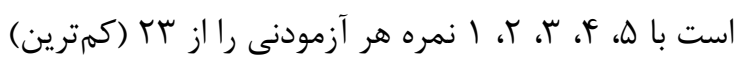

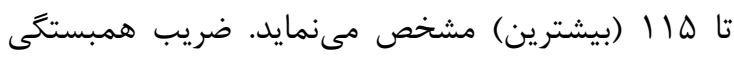
بين نمرههاى مقياس استرس زناشويى براى نمونه دوم درئن

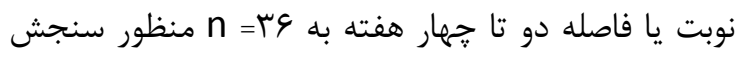

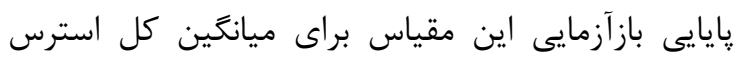

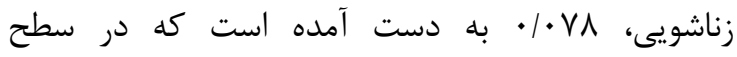
p p p p/001

$$
\text { آزمون است (1) (1). }
$$

روش تجزيه و تحليل آمارى: براى تجزيه و تحليل

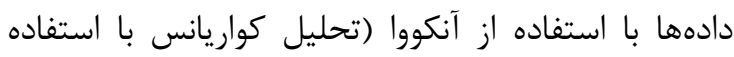

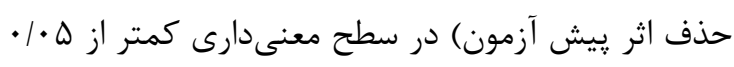

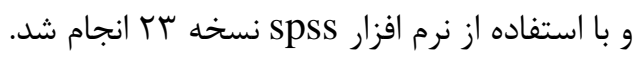

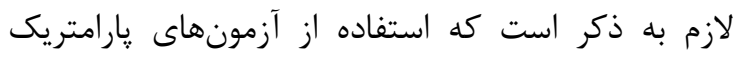

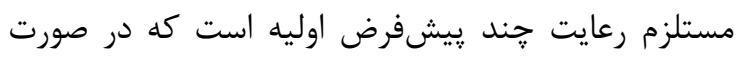

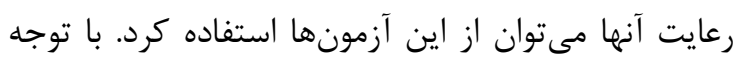

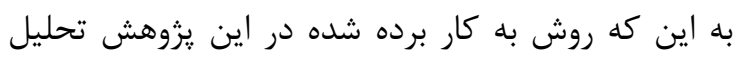

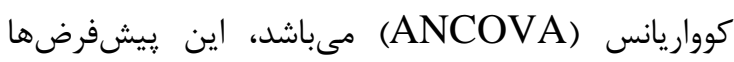

\footnotetext{
${ }^{4}$ Stockholm Tehran Marital Stress Scale
} 
آنها- يرداختن به امور ناتمام اعضا و تلاش براى تمام كردن آنها- كرفتن يس آزمون.

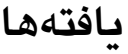

در اين قسمت از يزوهش نتايج حاصل از دادههاى آمارى و

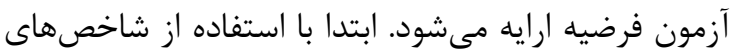
كرايش مركزى و شاخصهاى يراكندگى، خلاصهسازى

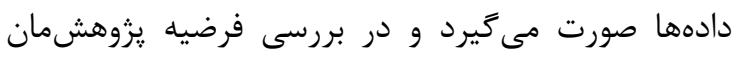

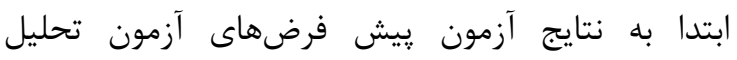
كوواريانس اشاره مىشود و سيس با استفاده از تحليل كوواريانس به تاييد يا رد فرض صفر مى يردازيمه.

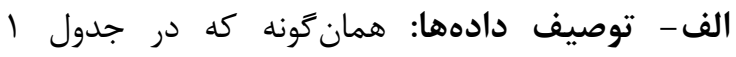
مشاهده مىشود ميانگَين سنى براى گروه آزمايش

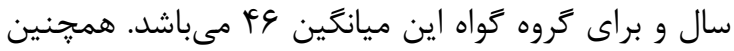
سطح تحصيلات، تعداد و وضعيت درمانى براى هر دو كروه آزمايش و كواه در جدول ا قابل مشاهده است.

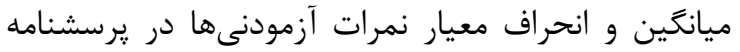

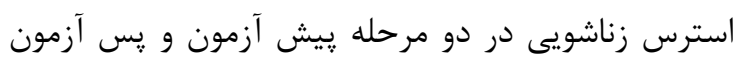

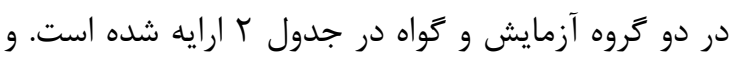
همانطور كه در اين جدول مشاهده مىشود، ميانگين

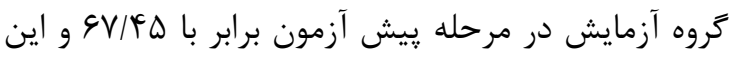

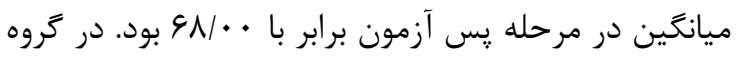

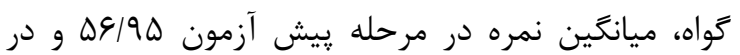

مرحله يس آزمون اين ميانكَين معادل 9 • 9 9 بود.

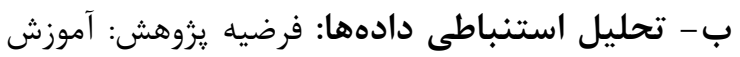

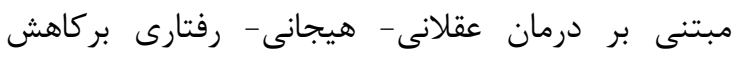

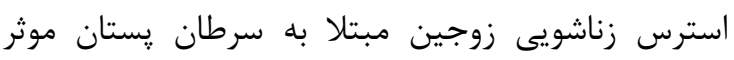

و بحث اعضاى كروه با هم در مورد اين كه شيوه انديشيدن آنها باعث واكنش آنها در برابر حوادث مى كرد درد. جلسه جهارم: مرور جلسات قبل و آشنايى بيشتر اعضاى

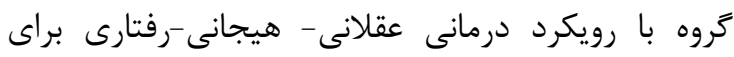

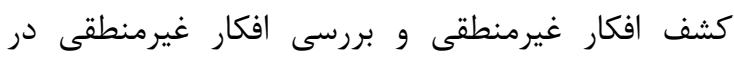

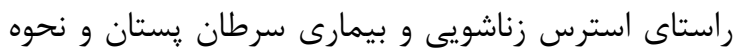
مجادله فعال با عقايد غيرعقلانى- در اين جلسه تكليف

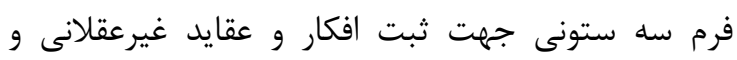

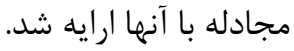
جلسه ينجم: بررسى گروهى و تحليل افكار، نگرشها، احساسات غيرمنطقى نسبت به خود و حوادث پِيرامون و

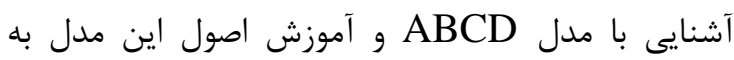
اعضا. در اين جلسه تكليف فرم سه ستونى با تاكيد بر ائ مدر به تغيير خودبيانىها آموزش و ارايه شد. جلسه ششم: شناخت افكار غيرمنطقى، بايدها، نبايدها و

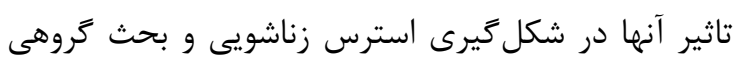

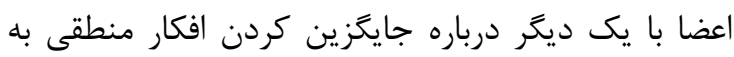
جاى افكار غيرمنطقى. تصويرسازى عقلانى هيجانى

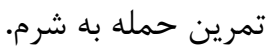
جلسه هفتم: مرور جلسات قبل و بيخيرى تكاليف-

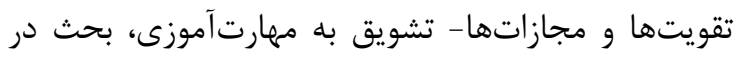

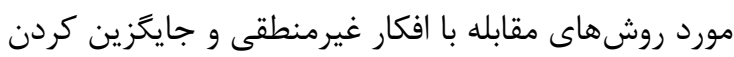
آن با افكار منطقى و دادن تكليف براى جلسه بعد؛ ايجاد

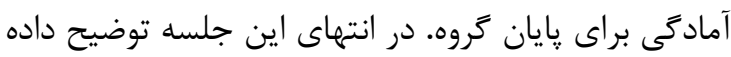

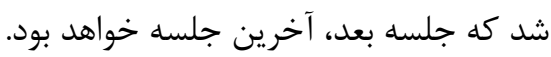
جلسه هشته: مرور تكليف جلسه قبل و انجام تمرينهاى عملى به شيوه گروهى و جمعبندى كليه جلسات- مورد

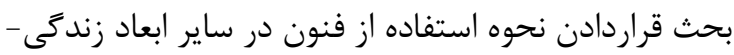

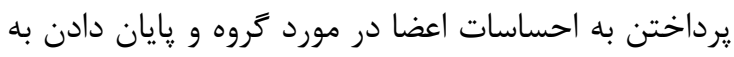

جدول ا: مشخصات دموكرافيك تروه آزمايش و كواه

\begin{tabular}{|c|c|c|c|c|c|c|c|c|c|}
\hline \multicolumn{3}{|c|}{ وضعيت درمان } & \multicolumn{2}{|c|}{ تعداد تروه } & \multicolumn{3}{|c|}{ تحصيلات } & \multirow[b]{2}{*}{ سيانغين } & \multirow[b]{2}{*}{ تروه } \\
\hline ير تودرمانى & شيمىدرمانى & جراحى & (مرد) & بيمار & 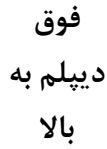 & دييلم & سيكل & & \\
\hline 1 & $\Delta$ & r & 9 & 9 & $r$ & 9 & 9 & $\psi_{\Lambda}$ & آزمايش \\
\hline r & f & r & 9 & 9 & r & $\Lambda$ & V & 14 & تواه \\
\hline
\end{tabular}


برحسب عضويت گروهى (دو گروه آزمايش و كواه) تفاوت معنادار است (1) مىشود و آموزش مبتنى بر درمان عقلانى- هيجانىرفتارى بر استرس زناشويى مؤثر بوده است.
نتايج تحليل كوواريانس براى بررسى تاثير عضويت گروهى بر ميزان نمرات استرس زناشويى در جدول بـ آمده است.

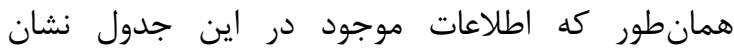

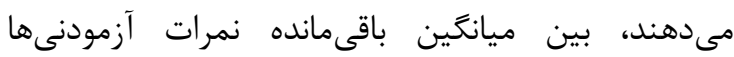

جدول ז: ميانگين و انحراف استاندارد نمرات آزمودنىها در يرسشنامه استرس زناشويى در دو مرحله

ييش آزمون و يس آزمون به تفكيك تروهها

\begin{tabular}{|c|c|c|c|c|c|}
\hline انحراف معيار & ميانگين & تعداد & كروه & مرحله & متغير \\
\hline $1 \% / 9 V$ & $G V / F \Delta$ & 11 & آزمايش & \multirow{2}{*}{ يِيش آزمون } & \multirow{4}{*}{ استرس زناشويى } \\
\hline IT/VG & $9 N / .$. & 11 & كواه & & \\
\hline $1 \cdot 19 V$ & $\Delta 9 / 9 \Delta$ & 11 & آزمايش & \multirow{2}{*}{ ֶس آزمون } & \\
\hline rr/Tו & $991 \cdot 9$ & 11 & كواه & & \\
\hline
\end{tabular}

جدول ץ: نتايج تحليل كوواريانس براى بررسى تاثير عضويت كروهى بر ميزان نمرات استرس زناشويى

\begin{tabular}{|c|c|c|c|c|c|c|c|}
\hline توان آزمون & ضريب إتا & معنادارى سطح & $\mathbf{F}$ & مجذانكين & درجه آزادى & مجذمورات & منبع \\
\hline .1991 & . \&ry & $\cdot / \cdot .1$ & $r T / V$. & $|F| Y / F \Delta$ & 1 & $|F| Y / F \Delta$ & بيش آزمون \\
\hline - IAVA & $\cdot / T \wedge G$ & $.1 \cdot .1$ & rq/VA & $r r \cdot N / q \Lambda$ & 1 & $r+N / 9 \Lambda$ & عضويت تروهى \\
\hline
\end{tabular}

از مهمترين و جديدترين آنها اشاره خواهيم كرد. بنابراين

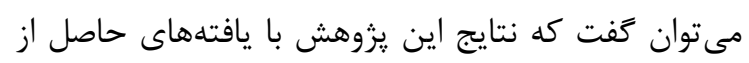

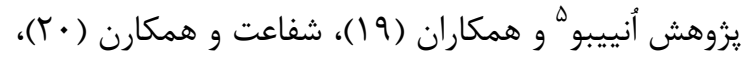

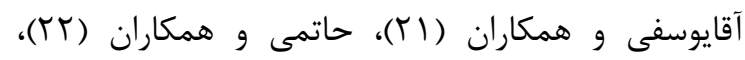

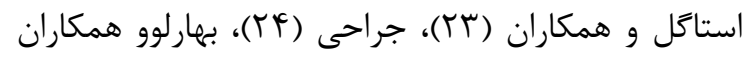

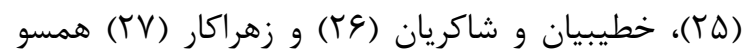
هدف از يزوهش حاضر، بررسى اثر بخشى آموزش مبتنى

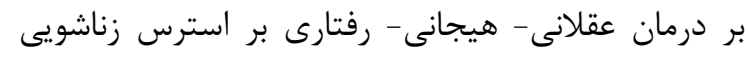

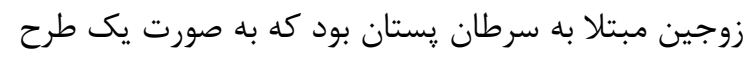

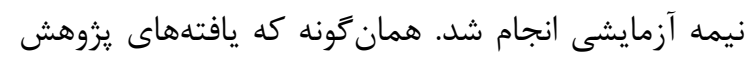

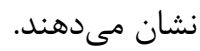
أنييبو و همكاران (19) در يزوهشى با عنوان اثربخشى عقد

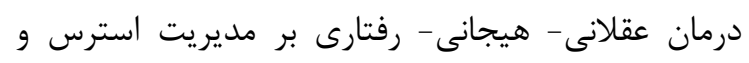
باورهاى غيرمنطقى معلمان مقطع ابتدايى در نيجريه به دانه

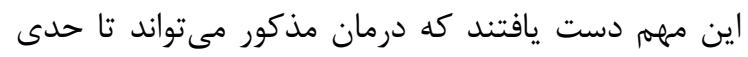

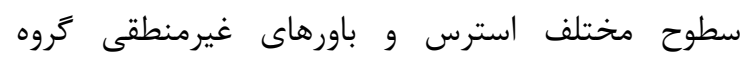
آزمايش را كاهش دهد مختف

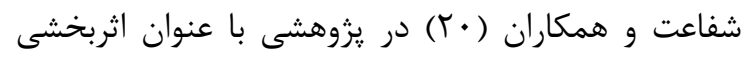

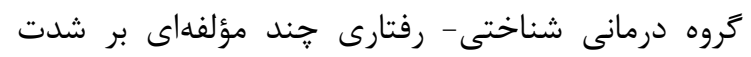

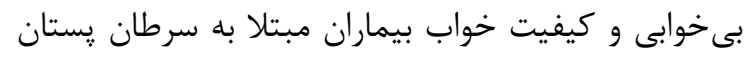

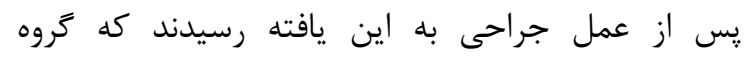

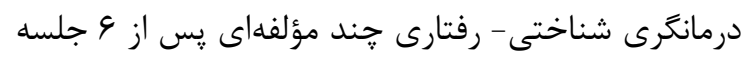

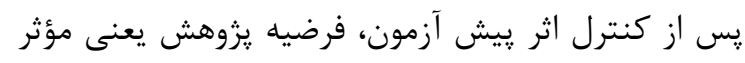

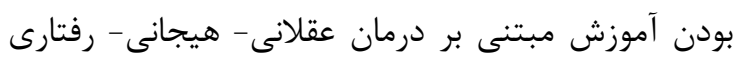
بر كاهش استرس زناشويى مورد تاييد قرار كرفت إنى . $\left.\mathrm{F}_{1,32}=r \mathrm{r} / \mathrm{V} \cdot \mathrm{p} \mathrm{p}<\cdot / \cdot 1\right)$ لذا مىتوان كَت كه آموزش مبتنى بر درمان عقلانى - •

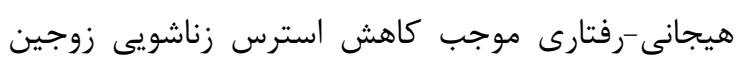

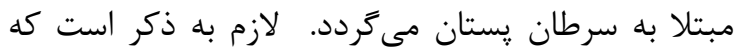

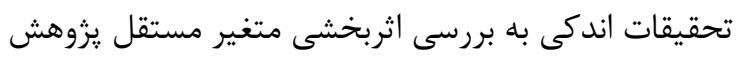

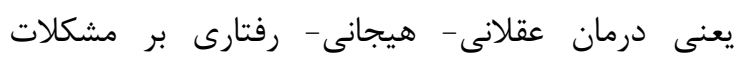

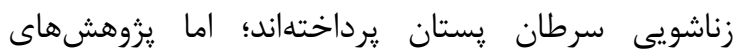

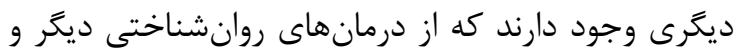

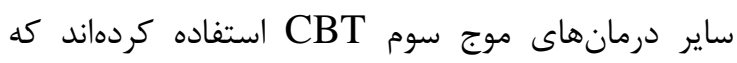
مى توان كفت با يزوهش ما همسو هستند كه به جند موند مورد 
درمان در يك فالوآٍ 11 ساله نرخ بازماندًان گروه آزمايش از گروه كواه بيشتر بوده است. جراحى (YF) در يزوهشى با عنوان اثربخشى گروه درمانى

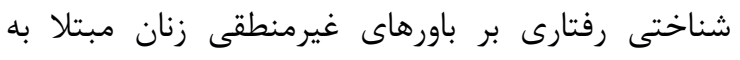

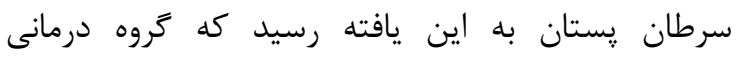
شناختى رفتارى باعث كاهش باورهاى غيرمنطقى زنان

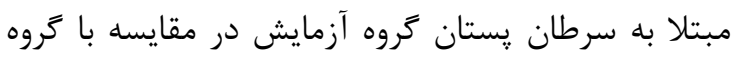

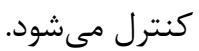

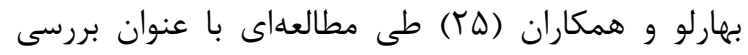

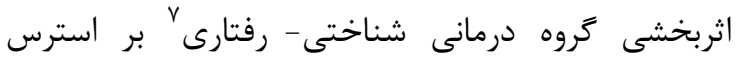

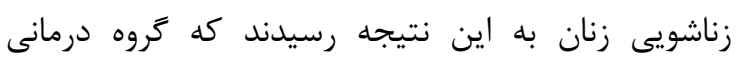

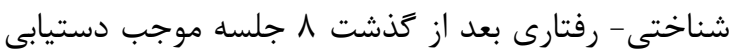

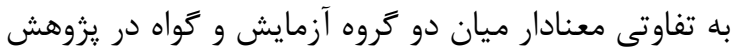

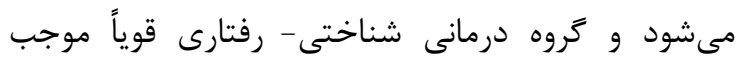
كاهش استرس زناشويى در زنان مىشود.

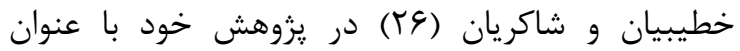

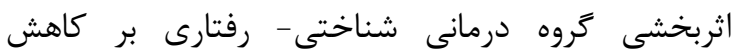

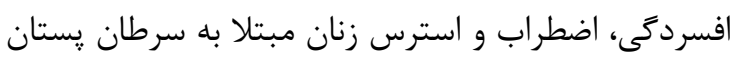
به اين نتيجه رسيدند كه كروه درمانى شناختى- رفتارى به طور معنادارى افسردىى، اضطراب و استرس زنان مبتلا به سرطان يستان را كاهش مى دهند.

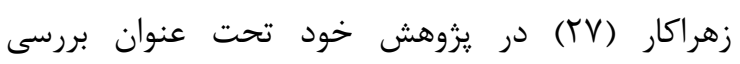

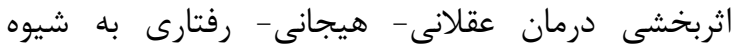

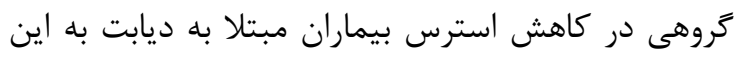

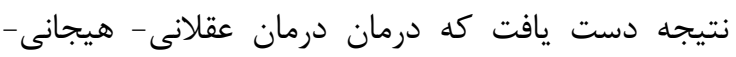
رفتارى در كاهش تمام نشانكان استرس موثر بوده است.

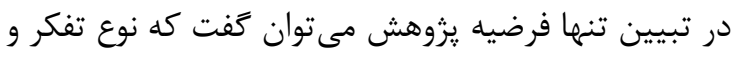

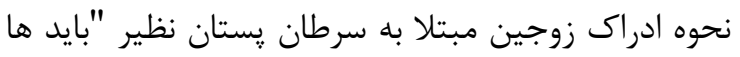

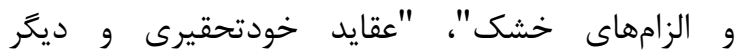

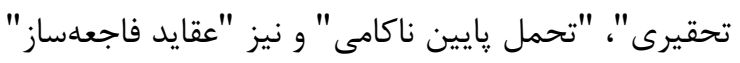

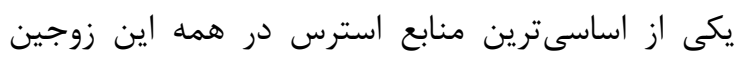

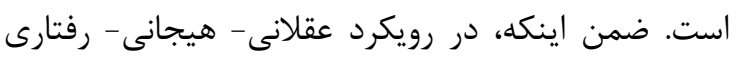
اليس نيز فرض اساسى اين است كه نحوه برداشت و تفسير افراد از اتفاقات و موقعيتهاى زنداسى إنى (نوع تفكر و

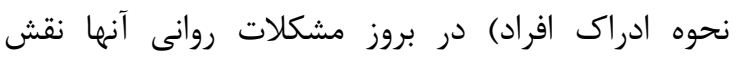

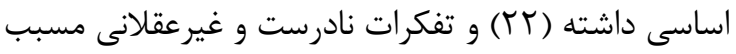

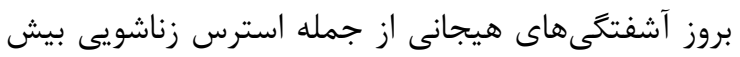

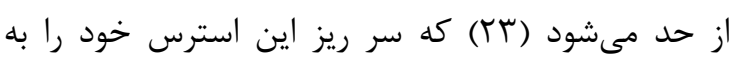

${ }^{7}$ Cognitive-behavioral stress management
آموزش اين رويكرد باعث بهبود شدت بىخوابى و كيفيت

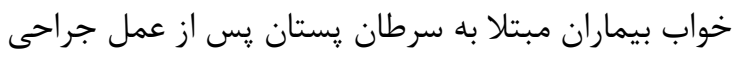

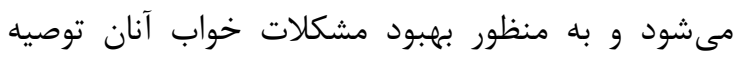
مى كردد.

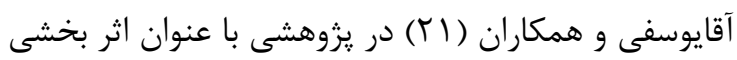
آموزش درمان شناختى- رفتارى بر كاهش خستى إنى

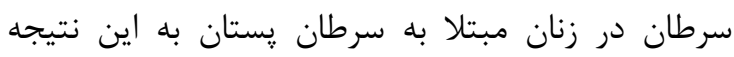

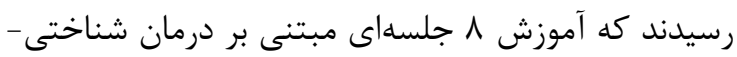

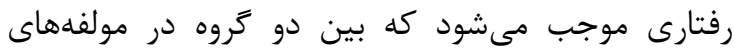

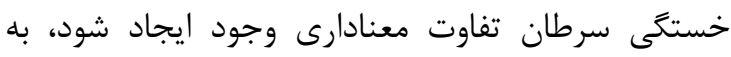

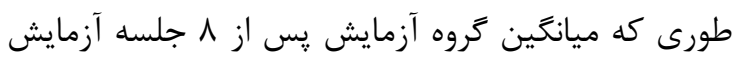

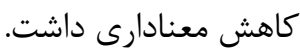

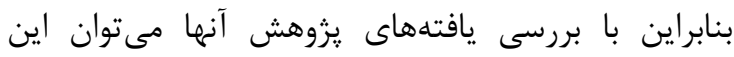

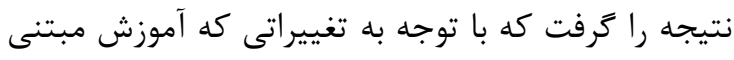
بر درمان شناختى-رفتارى در نكَرش و شناخت ايجاد

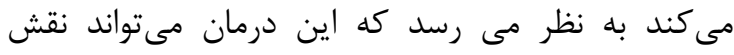

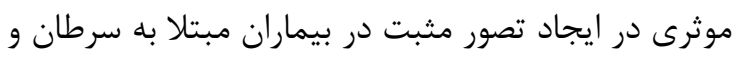
كاهش خستكى آنها داشته باشد.

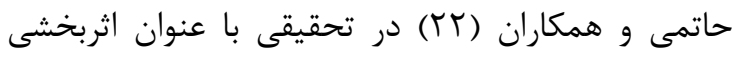
درمان شناختى- رفتارى بر خستخى، استرس ادراك شده

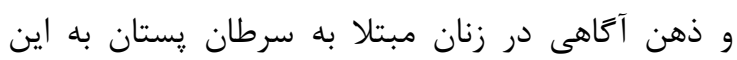

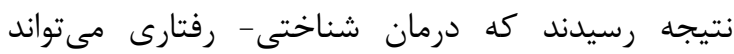
موجب كاهش خستخىى، استرس ادراك شده در زنان مبتلا

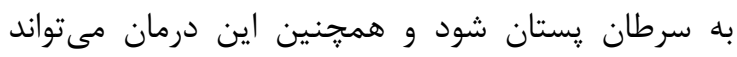

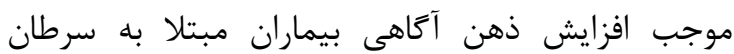

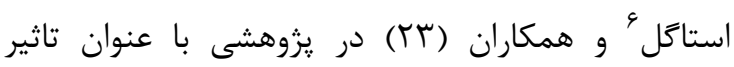

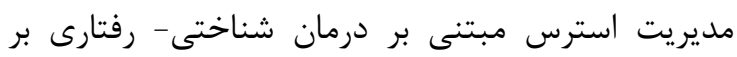

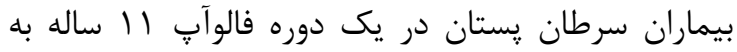
اين نتيجه رسيدند كه مديريت استرس مبتنى بر درمان

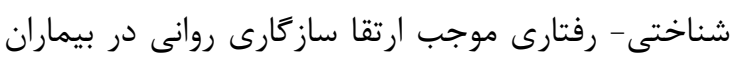

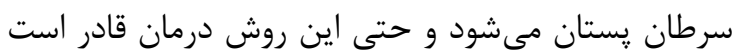

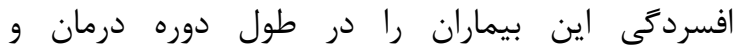

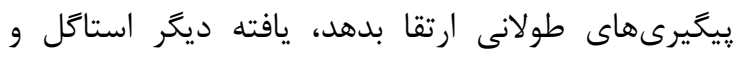

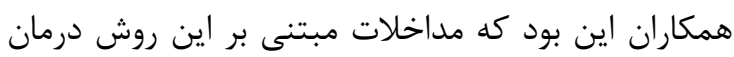

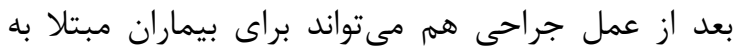

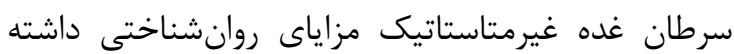

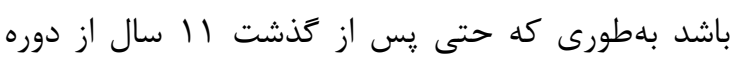

\footnotetext{
${ }^{6}$ Stagl
} 
عميقترى به دست بيايد. همجنين با توجه به اينكه اين

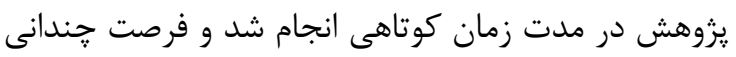

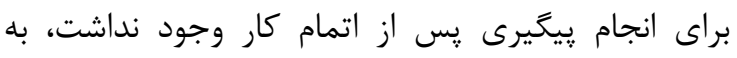

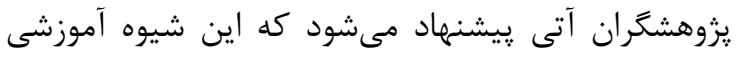
در تحقيقات آينده بصورت يِيَيرانه و با دورههاى فالوآي

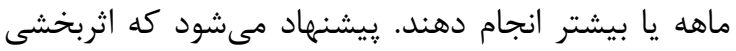

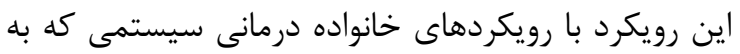

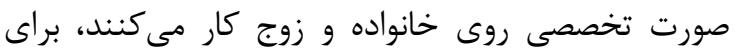
اين جامعه آمارى مقايسه شود. با توجه به اينكه آموزش آنادي

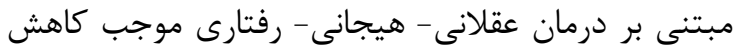

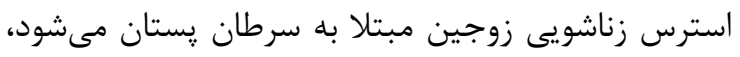

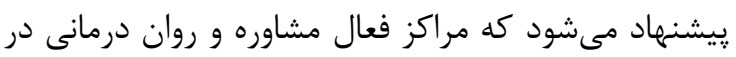
بيمارستانها و كلينيكهايى كه به صورت تخصني

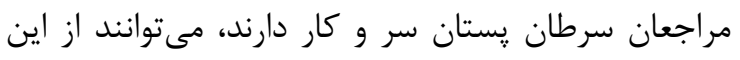
شيوه به منظور كاهش استرس زناشويى استفاده نمايند.

\section{نتيجهكيرى}

نحوه اثربخشى آموزش مبتنى بر درمان عقلانى - هيجانى رفتارى بر استرس زناشويى زوجين مبتلا به سرطان بستان از طريق كاهش استرس زناشويى در اين زوجين است. در

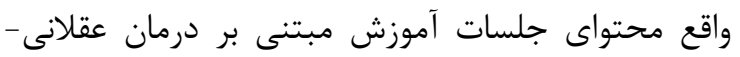

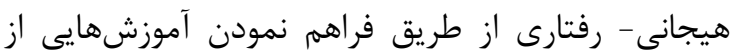

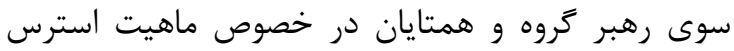

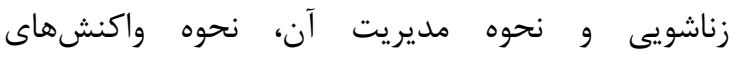

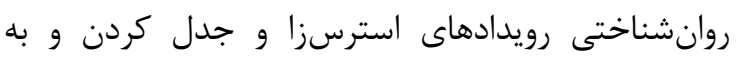
جالش كشيدن باورهاى غيرعقلانى در مورد بيمارى

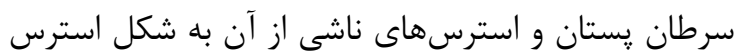

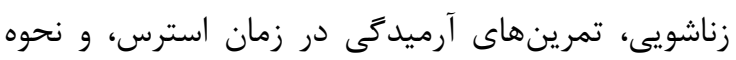
مقابله عقلانى-هيجانى و رفتارى با رويدادهاى بيرونى بـانه كاهش استرس زناشويى زوجين مبتلا به سرطان يستان

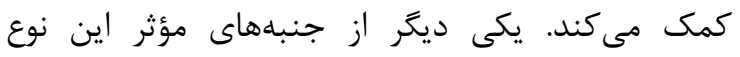

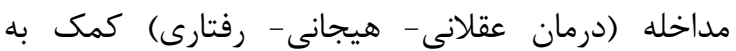
زوجين مبتلا به سرطان پستان است تا از طريق تكنيك هاني

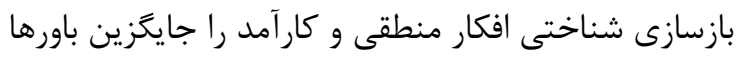

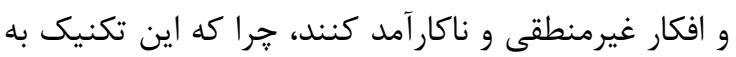
خودى خود در دراز مدت باعث مديريت و كاهش استرس زناشويى در اين زوجين مىشود.
شكل استرس زناشويى نشان مى دهد و تاثيرات مخربى بر زندكى زوجين مى گذارد. لذا هدف اين رويكرد مبارزه با

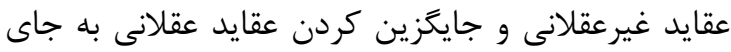

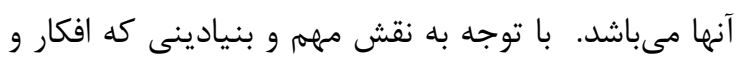
نوع نكرش افراد در ايجاد استرس زناشويى دارد و نيز با باديا توجه به اينكه هدف اصلى درمان عقلانى- هيجانى رفتارى ايجاد تغييرات تسكيندهنده از طريق تغيير افكار

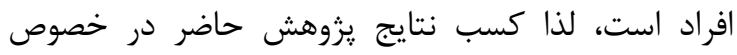
اثربخشى درمان عقلانى - هيجانى- رفتارى در كاهش

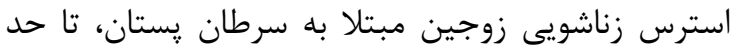
بسيار زيادى منطقى بهنظر مىرسد.

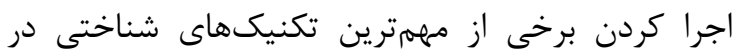

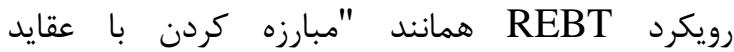
غيرعقلانى، تغيير دادن زبان خود و استفاده از شوخ طبعى ناند

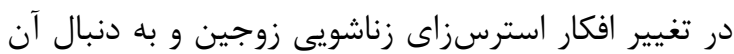
كاهش نشانهاى شناختى استرس زناشويى بسيار مؤثر

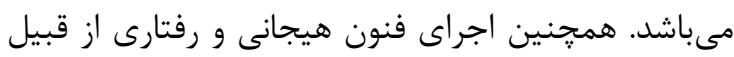
تصويرسازى عقلانى- هيجانى، ايفاى نقش و استفاده از خودتقويتى و خودمجازاتى در كاهش نشانهاى هيجانى و رفتارى استرس زناشويى زوجين مبتلا به سرطان يستان

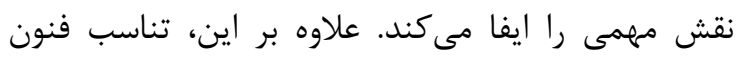
درمانى رويكرد REBT شامل فنون شناختى، هيجانى و ائي رفتارى را با نشانعان استرس زناشويى (شناختى، هيجانى

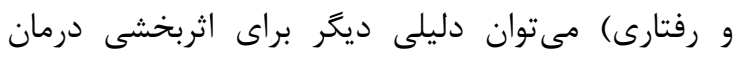

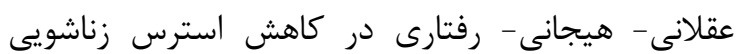
زوجين مبتلا به سرطان يستان دانست. لازم به ذكر است

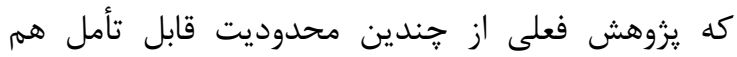

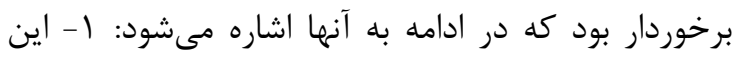
يزوهش در شهر قزوين انجام شده و در تعميم آن به شرايط ديكر بايد به تفاوت موقعيتها و فرهنگها تونها توجه

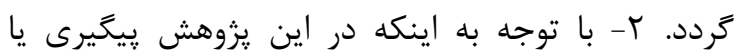

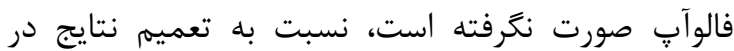
طولانى مدت بايد احتياط نمود. با توجه به اينكه آموزش

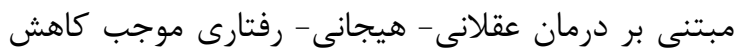

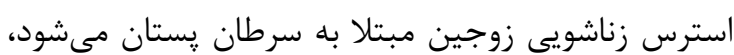

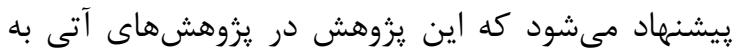

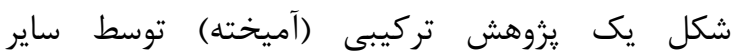

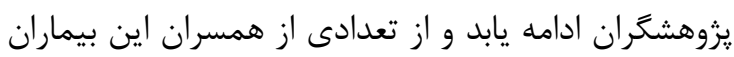

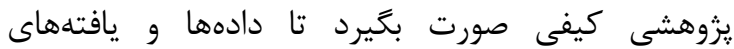




$$
\begin{aligned}
& \text { ״يرمردوند جَّينى دانشجوى كاشناسى ارشد مشاوره }
\end{aligned}
$$

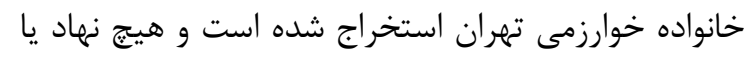

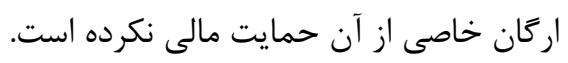

$$
\begin{aligned}
& \text { تعارض منافع } \\
& \text { نويسندًان اعلام مىدارند كه هيج تعارض منافعى در } \\
& \text { يزوهش حاضر وجود ندارد. }
\end{aligned}
$$

\section{References}

1. Kolden GG, Strauman TJ, Ward A, Kuta J, Woods TE, Schneider KL, Heerey E, Sanborn L, Burt C, Millbrandt L, Kalin NH. A pilot study of group exercise training (GET) for women with primary breast cancer: feasibility and health benefits. Psycho Oncology: Journal of the Psychological, Social and Behavioral Dimensions of Cancer. 2002; 11(5):44756.

2. Zahlis EH, Lewis FM. Coming to grips with breast cancer: the spouse's xperience with his wife's first six months. Journal of psychosocial oncology. 2010; 28(1):79-97.

3. Rezaian, A. Analysis and design of System. Tehran: Published by Samt. 2014.

4. Alacacioglu A, Ulger E, Varol U, Yildiz I, Salman T, Bayoglu V, Dirican A, Demir L, Akyol M, Yildiz Y, Tarhan MO. Depression, anxiety and sexual satisfaction in breast cancer patients and their partnersizmir oncology group study. Asian Pac J Cancer Prev. 2014; 15(24):10631-6.

5. Northouse LL. Psychological impact of the diagnosis of breast cancer on the patient and her family. Journal of the American Medical Women's Association (1972). 1992; 47(5):161-4.

6. Northouse LL, Mood D, Kershaw T, Schafenacker A, Mellon S, Walker J, Galvin E, Decker V. Quality of life of women with recurrent breast cancer and their family members. Journal of Clinical Oncology. 2002; 20(19): 4050-64.

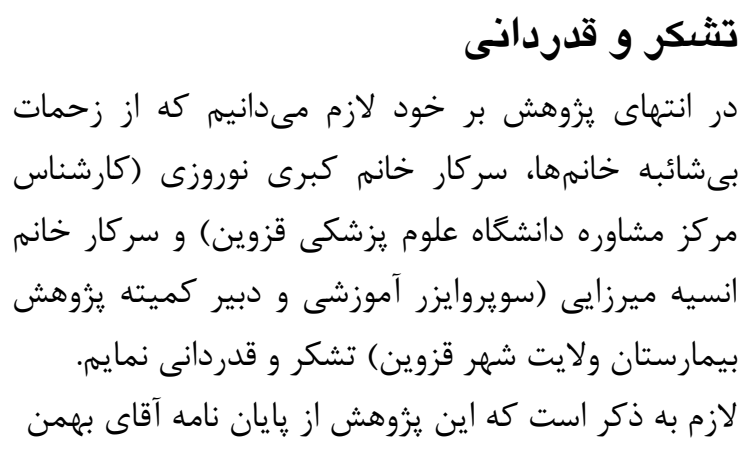

7. Esfandiari Dolabi Z, Joulaei A, Asli Azad M. Comparison of marital satisfaction and general health among breast cancer patients with breast evacuation, breast keeping and cancer free women in Tehran. IJRR. 2015; 1(4):39-48.

8. Jankowska M. Sexual functioning in young women in the context of breast cancer treatment. Reports of Practical Oncology \& Radiotherapy. 2013; 18(4): 193-200.

9. Mirghaffari M. The effect of emotionfocused therapy approach on reducing marital stress in pars oil man shiftwork. Unpublished dissertation, kharazmi university, Tehran. 2014.

10. Sakizade F, Zahrakar K, Sanaie ZB \& Ahmadi, M. the Effectiveness of martial skills training based on Guttmann model on the marital happiness. journal of counseling research. 2015; 13(52): 37-51.

11. Revenson TA, Kayser KE, Bodenmann GE. Couples coping with stress: Emerging perspectives on dyadic coping. American Psychological Association; 2005.

12. Shakarami M, davarniya $R$, zahrakar K. A study of effectiveness of solutionfocused brief therapy (SFBT) on reducing marital stress in women. sjimu. 2014; 22(4):18-26.

13. Zahlis EH, Shands ME. Breast cancer: Demands of the illness on the patient's partner. Journal of Psychosocial Oncology. 1991; 9(1):75-93. 
14. Zahrakar K. A Study of Effectiveness of Rational, Emotive, Behavior Therapy (REBT) with Group Method on Decrease of Stress among Diabetic Patients. Knowledge \& Health. 2013; 7(4):160-4.

15. Corey G. Theory and practice of counseling and psychotherapy. Nelson ducation; 2015.

16. Dryden W. Rational emotive behaviour therapy: Distinctive features. Routledge; 2014 Dec 8. Translated by Movahhed R, Tehran Arjmand publication 2016.

17. Sharf RS. Theories of psychotherapy \& counseling: Concepts and cases. Cengage Learning 2015.

18. Shamsipoor M, Besharat MA, Sadeghian S. relationship between marital stress and depression symptoms in women with coronary heart disease and healthy women. Journal of Psychology and Education. 2005; 35(2): 21-37.

19. Onuigbo LN, Eseadi C, Ugwoke SC, Nwobi AU, Anyanwu JI, Okeke FC, Agu PU, Oboegbulem AI, Chinweuba NH, Agundu UV, Ololo KO. Effect of rational emotive behavior therapy on stress management and irrational beliefs of special education teachers in Nigerian elementary schools. Medicine. 2018; 97(37): 1-11.

20. Shafaat N, Makvand Hosseini S, Rezaei A M. Effectiveness of Multi-Components Cognitive-behavioral Therapy on Insomnia Intensity and Quality of sleep among Breast Cancer Patients after Surgery. 2017; 11(2):82-91.

21. Aghayousefi AR, Dehestani M, Sharifi Saki S. Effectiveness of CognitiveBehavioral Education in Reduction of Exhaustion of Cancer of Women Suffering from Breast Cancer. Health Psychology. 2016; 5(19):5-17.

22. Hatami m, Hasani j, Johnfaza m. The Effectiveness of Cognitive-Behavioral Therapy on Fatigue, Perceived Stress and Mindfulness in Women with Breast Cancer. M.a psychology- unpublished dissertation - Kharazmi University 2016.

23. Stagl JM, Bouchard LC, Lechner SC, Blomberg BB, Gudenkauf LM, Jutagir DR, Glück S, Derhagopian RP, Carver CS, Antoni MH. Long term psychological benefits of cognitive behavioral stress management for women with breast cancer: 11 year followup of a randomized controlled trial. Cancer. 2015; 121(11): 1873-81.

24. Jarrahi sh. The Effectiveness of Cognitive-Behavioral Group Therapy on Irrational Beliefs in Women with Breast Cancer. Second National Conference on Research and Therapy in Clinical Psychology 2015.

25. Baharloo Gh, Zarei I, Karami B R. Ismaili M. Effectiveness of cognitivebehavioral group therapy on marital stress in women. The first global conferences on modern research in psychology and social sciences 2016.

26. Khatibian M, Shakerian A. The Effectiveness of Cognitive-Behavioral Group Therapy on Depression, Anxiety and Stress in Women with breast cancer. 2014; 19(4): 91-99.

27. Ellis A, Dryden W. The practice of rational emotive behavior therapy. Springer publishing company 2007.

28. Dryden W. Rational emotive behaviour therapy: Distinctive features. Routledge 2014. 